(1)

GeORgE Fox

UNIVERSITY

\section{Digital Commons @ George Fox University}

2016

Exploring Pietism as an Intermediary for Lutheran-Pentecostal Dialogue

Daniel L. Brunner

Leah Payne

Follow this and additional works at: https://digitalcommons.georgefox.edu/gfes

Part of the Christian Denominations and Sects Commons, and the Christianity Commons 


\title{
Exploring Pietism as an Intermediary for
}

\section{Lutheran-Pentecostal Dialogue}

\author{
By Daniel L. Brunner and Leah Payne
}

\begin{abstract}
The authors, a Lutheran and a Pentecostal, explore similarities and differences between their respective traditions using German Lutheran Pietism as a bridge. Parallels include conversionism, devotion to the Bible, practical holiness, missional activism, and opposition to the shortcomings of the religious status quo. Key divergences between the movements include the role of the sacraments, the place of manifestational gifts, and eschatology. The authors highlight how Pietism can be a useful channel and translator for dialogue.
\end{abstract}

$\underline{\text { Key Terms: }}$ Lutheran, Pentecostalism, Pietism, ecumenism, spirituality

\section{Filling the Dialogue Gap}

Christian ecumenical dialogue has flourished in recent decades. Indeed, groups with longstanding estrangements have begun engaging in profitable theological, missional, ecclesiological, and praxisoriented conversations. ${ }^{1}$ Although Lutherans and Pentecostals have participated in this trend-for example, both groups have entered into helpful dialogue with Roman Catholics - only recently have they entered into such dialogue with one another. ${ }^{2}$

There are many possible explanations for this lacuna. Their family trees are rooted on different continents: Lutheranism arose out of theological and political unrest in sixteenth-century Germany, while Pentecostalism began in the nineteenth and twentieth centuries as a series of revivals in India,
Wales, and the United States. Lutheranism has long treasured theology as a discipline; Pentecostalism, by contrast, has focused on praxis. In addition, Lutheran theological discourse began in and has flourished in university settings; historically, Pentecostals have lacked the means and sometimes even the desire to engage in traditional theological conversations. Other factors, related to race and class, also certainly come into play.

The authors of this article wish to fill this gap, not by speaking for all Lutherans or all Pentecostals, but by modeling a relational dialogue between representatives of distinct outworkings of each movement. Brunner is an ordained Lutheran (ELCA) and scholar of Pietism, and Payne is a (Foursquare) scholar of Pentecostalism; both teach at a multidenominational, evangelical seminary.

Our approach is to use classic German Lutheran Pietism as a bridge for dialogue. Our method

Daniel L. Brunner is Professor of Christian History and Formation at George Fox Evangelical Seminary in Portland, Oregon. His research interests include German Lutheran Pietism, Christian spirituality and formation, and eco-theology. He recently co-authored Introducing Evangelical Ecotheology: Foundations in Scripture, Theologis History, and Praxis (Baker, 2014).

Leah Payne is Assistant Professor of Christian Studies at George Fox Evangelical Seminary in Portland, Oregon. Her research interests include religion and popular culture, gender, race, and class theory. Her first book, Gender and Pentecostal Revivalism: Making a Female Ministry in the Early Twentieth Century (Palgrave, 2015) won the 2016 Pneuma: The Journal of the Society for Pentecostal Studies Book Award, and her second book explores political theology within American Pentecostalism. 
probes theology without prioritizing it; praxis, mission, and spirituality are equally profitable points of entry. Toward that end, our primary undertaking is to highlight particular areas of accord and potential solidarity between historical Lutheran Pietism and Pentecostalism. In the end, to be sure, significant differences on many levels will remain. Nonetheless, we hope to model that dialogue is possible and even fruitful. Before we do the work of comparison and contrast, it is necessary to define the scope of our particular movements.

\section{Defining German Lutheran Pietism and Pentecostalism}

F. Ernest Stoeffler, the first English-speaking scholar of Pietism, wrote that Pietism is "one of the least understood movements in the history of Christianity." 3 Scholars debate both the definition and scope of historical Pietism. ${ }^{4}$ Generally speaking, Pietist scholarship sorts itself along two lines. ${ }^{5}$ The first circumscribes Pietism more narrowly, as a renewal movement within continental Protestantism, beginning with Philipp Jakob Spener's reforms put forward in Pia Desideria (Pious Desires). ${ }^{6}$ Other scholars, however, view Pietism more broadly and inclusively, as a "crisis of piety" that had parallel expressions in Puritanism, the nadere Reformatie (Dutch Further Reformation), the Arndtsche Frömmigkeitsbewegung (Arndt's Movement of Piety), and the English-speaking Evangelical Revivals.

For the purpose of this article, we take a stricter understanding of Pietism, as a "new" reformation within the Lutheran church in Germany in the late seventeenth and early eighteenth centuries, which sought to revive the church through personal spiritual renewal. ${ }^{8}$ It saw itself as a new or "second" reformation; Luther's Reformation, they stated, was (appropriately) aimed at doctrine, while theirs targeted the Christian life. ${ }^{9}$ Its maxim was to transform the church and society by transforming the individual. In the earliest English account of the history of Pietism, Anthony Boehm offered three characteristics of Lutheran Pietism: 1) it spoke out against perceived abuses in the Lutheran church, especially as represented by Lutheran scholastic orthodoxy; 2) it stressed practical and personal holiness; and 3) it emphasized a living, experiential faith à la Luther's Preface to Romans. ${ }^{10}$ It is enlightening to note how Boehm's characteristics of Pietism from the early eighteenth century compare with Stoeffler's scholarly perspective. He delineates four foci in German Pietism: experiential, perfectionistic, biblical, and oppositive. ${ }^{11}$ Boehm presupposed the biblical nature of Pietism and would see no need to name it as a distinct characteristic; otherwise, their depictions align neatly.

Not only do Boehm's and Stoeffler's characterizations of Pietism compare favorably with each other, but both share strong affinities with David Bebbington's broadly recognized definition of evangelicalism: conversionism, activism, biblicism, and crucicentrism. ${ }^{12}$ These similarities buttress Mark Noll's statement that the "convictions, practices, habits and oppositions" of evangelicalism "resemble what Europeans describe as "pietism." 13 The early expression of German Lutheran Pietism under Spener and August Hermann Francke in Halle presaged in important ways the later Evangelical Revivals. ${ }^{14}$

In many ways American Pentecostalism does not have a clear theological family tree. Its founders came from diverse theological backgrounds that include Methodism, Catholicism, Presbyterianism, and Friends, to name a few. The movement can be seen as a theological and practical grandchild of Pietism because the movement was an early twentieth-century blend of Wesleyan-Holiness theology, which was greatly influenced by German Pietism ${ }^{15}$ and American revivalist practices. The theology of nineteenth-century Wesleyan-Holiness movements has significantly shaped the development of Pentecostalism. ${ }^{16}$ In the early days of the movement, Pentecostal preaching included many Wesleyan-Holiness themes. For example, Pentecostals encouraged their flocks to dress according to strict holiness guidelines, abstain from alcohol, avoid social dances (although dancing "in the Spirit" during church was encouraged), and refuse to watch movies as film emerged as a popular form of entertainment. Pentecostal pastors also advised 
their followers to engage in holiness activities such as Bible study, caring for the poor, evangelism, and prayer for divine healing.

The theology of early Pentecostalism is, for the most part, subject to its revivalist approach. Revivalism, at least the American variety, is a set of practices historians typically trace to the "awakening" within American Protestantism in the eighteenth century. ${ }^{17}$ During this "Great Awakening," revivalists sought to breathe life into what they saw as an ailing American Protestantism. ${ }^{18}$ Revivalist practitioners came from diverse denominational and theological backgrounds, but they shared several common methods, including individual conversions, emotive responses to worship services, other "scandalous practices" (e.g., lifting hands, crying, fainting, etc.), and animated meetings or "revivals." 19 Pentecostals quickly became distinguished by their typical (although not exclusive) practices of glossolalia, or speaking in tongues. In addition, they were well known for other rituals including faith healings and prophetic utterances.

That Pentecostals have not placed a strong value on any particular theological strand creates a problem when it comes to comparing the movement to the theologically rich tradition of Lutheranism. We are persuaded that German Lutheran Pietism can serve as a useful intermediary. To be sure, historically, certain representatives of late Lutheran scholastic orthodoxy called into question the "Lutheran-ness" of the Pietism of Spener and Francke. Nonetheless, in spite of the fact that Pietism often functioned impatiently and belligerently within German Lutheranism, it identified resolutely with Luther, and its essential orthodoxy consistently has been reaffirmed. ${ }^{20}$ Carter Lindberg has drawn attention to the numerous ways in which Lutheran Pietism was a key historical link between sixteenth-century Lutheranism and the late-twentieth-century charismatic renewal. ${ }^{21}$ In addition, because Pietist practice in noteworthy ways foreshadowed the English Evangelical revivals, it also shares important commonalities with a Pentecostalism that is included within the broad sweep of American evangelicalism. Pietism therefore is a unique resource for building bridges between Lutheranism and Pentecostalism.
In what follows we bring to light five parallels between our two representative movements; following that, we mention three ways in which they diverge.

\section{Parallels Between Pietism and Pentecostalism}

\section{Conversion}

Both Pietism and Pentecostalism place a high value on conversion. For Pietists, conversionism was rooted in Luther's Preface to Romans (1522), in which he described faith as "a work of God in us, which changes us and brings us to birth anew from God (cf. John 1). It kills the old Adam, makes us completely different people in heart, mind, senses, and all our powers, and brings the Holy Spirit with it. What a living, creative, active powerful thing is faith!" 22 Pietists drew on the early Luther for their stress on the radical inward renewal of the individual. The language surrounding this spiritual transformation varied. Some, following Johann Arndt in True Christianity, talked about the "renewal" or "restoration" of the divine image within fallen humanity. Spener preferred "rebirth," which Francke later morphed into a more unbending, three-stage ordo of "conversion." 23 There was no agreed-upon language for or method of transformation; indeed, a young Nikolaus Zinzendorf reacted strongly against Francke's rigid process during his student years at Halle. The focus on conversion, by whatever name, highlights the significance of the experiential within Pietism.

Like the Wesleyans from which they proceed, and like many other American Evangelicals, Pentecostals also value the experience of conversion. "We preach old-time repentance, old-time conversion," claimed early Pentecostal founder and theologian William Seymour. ${ }^{24}$ Early Pentecostal literature was replete with tales of dramatic conversions to Pentecostal manifestations, and each conversion story demonstrated the relationship between conversion and spirituality for Pentecostal practitioners. "He is 
over all the trials," wrote one Joseph Robbins, a typical convert. "He is over and underneath, and all around. Never since I have known God, when all my friends was agin [sic] me, I never thought that was too hard. I didn't think I had to bear it. He stood between me and the trial. He is my Burden-bearer. Some people that can read, good scholars never learn that, but I learned it as soon as I got converted." 25

Individual conversion narratives such as theseoften referred to as "testimonies"-were prominent parts of Pentecostal worship services. They were reprinted in Pentecostal literature, and in later years were broadcast on the radio and television. These conversions served to demonstrate the spiritual power of the Pentecostal meeting and the efficacy of the Pentecostal proclamation of an immediate encounter with the Holy Spirit. Similar to the notion of rebirth or renewal in Pietism, Pentecostals discussed their lives in terms of "death" before conversion and "life" afterward. "I got converted Tuesday night," claimed Robbins, "and on Friday night I found my Jesus was my Burdenbearer, and He has been ever since." 26

\section{Biblicism}

Biblicism is another commonality shared by Pietism and Pentecostalism. ${ }^{27}$ The biblicism of Pietism carries distinct Lutheran overtones, with its emphasis on the centrality of the gospel message and of Christ as "the end and scope of the divine Scriptures." 28 The purpose of the divine Word was to reveal Christ, and the result of that encounter was salvation through faith. Within Pietism the Scriptures also took on a devotional function and served to guide a life of holiness, self-examination, and service. At the same time, the biblicism of the Pietists should be juxtaposed with what they saw as the academic logomachy of Protestant orthodox theologians. ${ }^{29}$ Their denunciation of empty scholarly logic reflects Luther's own renowned assertion that "reason is the devil's whore." Within Pietism, therefore, the authority of the Bible arose from a personal, experiential knowledge; assurance came from interior verification rather educated argument.
Pietism is part of an epistemological shift to experience as the foundation of knowing. ${ }^{30}$ That interior verification of experience was, for Pietists, tied to their perception of the working of God's intervention in the world; for example, Francke pointed out that one could see in the work at Halle "the Marvellous Footsteps of Divine Providence." 31 By merging their particular biblicism with experiential authentication and divine providentialism, Pietists developed an effective means for resisting orthodox scholarly argumentation.

Pentecostal biblicism reflected pietistic notions of authority and experience. Unlike liberal and fundamentalist Protestants of the early twentieth century, Pentecostals did not engage in discourse about whether or not the Bible's authority depended upon historical-critical verification, something that even so did not prevent them from embracing the Bible. ${ }^{32}$ On the contrary, Pentecostals used the Bible as a primary source of authority for verifying the doctrines, experiences, and practices of Pentecostal worshipers. ${ }^{33}$ They used the Bible as a blueprint for understanding and then communicating their own supernatural experiences. "These messages," wrote one Pentecostal adherent of controversial Pentecostal teachings about divine healing, "have always been tested by the Word of God; not one has been contrary to the plain teachings of the Bible." ${ }^{34}$ Pentecostals also reported that Bible reading had power to induce typical spiritual experiences like speaking in tongues. "One mother," reported a Pentecostal periodical, "got the baptism [in the Holy Spirit-i.e., tongues] at a Bible reading." 35

\section{Practical Holiness}

Another shared characteristic of Pietism and Pentecostalism is their hunger for practical holiness. The term Pietist, originally used derogatorily, referred to an emphasis among certain students on practical "piety" or holiness of life. As early as 1670 Spener established small groups for lay leaders in his Frankfurt congregation called collegia pietatis, fellowships or societies of piety. ${ }^{36}$ In Pia Desideria Spener called on universities to pay attention to more than 
academics: "students should unceasingly have it impressed upon them that holy life is not of less consequence than diligence and study, indeed that study without piety is worthless." ${ }^{37}$ Pietists were vigilant, as Lutherans, to emphasize that personal holiness and practical piety were the indispensable fruit of justification by faith. Nonetheless, some of their orthodox opponents saw the focus on piety and holiness of life as salvation by works; for their part, the Pietists charged their rivals with moral indifference. While at times the call to praxis pietatis carried perfectionistic overtones, it also stirred many to devotional exercises and missional outreach. ${ }^{38}$

Like their theological predecessors in the Pietist-influenced Wesleyan-Holiness tradition, Pentecostals also embraced practical holiness as a sign of the presence of the Holy Spirit. Many Pentecostals fretted about the "worldly" society in which they lived and worked, and responded by embracing strict codes for holy living - refraining from dancing, drinking, going to movies, playing cards, etc., and adopting Bible reading, evangelism, caring for the poor, etc. ${ }^{39}$ One of the primary signifiers of the spiritual state of holiness was outward appearance. ${ }^{40}$ "People who got this great grace of sanctification," wrote one Pentecostal believer, "pulled off their gaudy dress, and stripped off their jewelry." 41 Thus, holy living and modest clothing had a sacramental function: outward appearance displayed inward godliness and power. ${ }^{42}$ This sanctified power compelled adherents to do good works.

\section{Activism}

Related to the practice of holiness, both Pietism and Pentecostalism reveal a distinct activism. Not infrequently scholars have highlighted the inward and subjective aspects of Pietism to the exclusion of its missional activity. ${ }^{43}$ That kind of imbalanced interpretation disregards, in particular, the far-reaching enterprises of Francke at Halle. He and his representatives, in contrast to their orthodox contemporaries, established a celebrated institution for the support and care of orphans and widows, started schools for both nobility and the underprivileged, sent missionaries to the southeastern coast of India, founded a Bible society for the printing and distribution of Scripture and devotional literature, and initiated ecumenical cooperation with Anglicans and New England Congregationalists. ${ }^{44}$ Reports of the "success" of these diverse initiatives were published around the world and provided impetus to many similar endeavours. While the charitable, educational, missional, and ecumenical undertakings of the Halle Pietists are striking, especially for their time and in comparison to most of their Protestant contemporaries, it deserves mention that seldom did Pietist leaders challenge systemic injustice. They sought primarily to transform the church and society by transforming the individual, and the transformation of the individual was rooted in spiritual conversion and renewal.

Pentecostals shared with their Pietist predecessors an interest in transforming their world by beginning with individual renewal and good works. True to their roots in the Holiness movement, Pentecostals believed activism was a key indicator of the inner work of the Holy Spirit in the believer. ${ }^{45}$ Those who were able to throw off the sinful world around them showed their righteousness by engaging in missionary work, caring for the poor, refusing to gamble or dance, reading the Bible, praying, fasting, and more. Pentecostals sought converts to holiness and tied their activism directly to a healthy spiritual life. Born during the height of the temperance movement, early Pentecostal activism often was connected to abstaining from alcohol. "Satan does not like us to call Indian Christians to a life of holiness and separation unto God," wrote one Pentecostal missionary to India. "God has been manifesting His power among us," she continued, "casting out the demons of drink from those who were possessed by them and saving them entirely from the desire of liquor and giving men the freedom to pray and a great longing for purity." 46

\section{An Oppositional Element}

Within any "ism" or movement for renewal or reformation there exists an oppositional element, a 
desire to "assert itself against a dominant pattern." ${ }^{7}$ Both Pietism and Pentecostalism reacted against what they perceived to be shortcomings of the religious status quo. Pietism certainly engaged in a fervent polemic with a later, more ossified version of Lutheran scholastic orthodoxy. And yet, ironically, Pietism arose out of a spirit of piety and reform that existed alongside a passion for "pure doctrine" within earlier Lutheran orthodoxy, chiefly with someone like Arndt. As Pietism developed into a self-conscious movement, especially after the publication of Pia Desideria, it threatened orthodox theologians like Valentin Ernst Löscher.

Spener himself was an irenic churchman whose theology had only a few, though important, departures from the prevailing orthodoxy. Francke, though, was much more rambunctious. In a 1698 sermon he referred to orthodox clergy in his area as "false prophets," claiming, in the words of a sympathetic contemporary, "that the general degeneracy of Christianity was owing principally to the lukewarmness and deadness of the clergy," 48 Pietism was a "heart religion" that countered what it saw as the coldness and formality of the dominant Lutheranism.

Like Pietists, Pentecostals also were concerned with coldness and formality of American Protestantism. "In these days of cold formalism, of Higher Criticism in our leading seats of learning, and of rank infidelity and doctrines of demons rampant through the country," wrote F. L. Juillrat, "conscientious Christians need to be on alert against the wiles of the enemy of their souls." 49 Christians needed to be careful, according to Pentecostals, because excessive interest in dogma had the potential to stymie the "power of the Holy Spirit." "The Welsh revival has gone flat," wrote Samuel J. Mead. "The churches heard the music, felt the power, reached out, and tried to graft it on their creeds and formalism and they have lost their power." The cure for the hardening and intractability of Protestantism was the fire of the Holy Spirit. "We are all together too formal," continued Mead. "We need the power of the Holy Spirit." $" 50$

\section{Differences Between Pietism and Pentecostalism}

\section{Sacramentalism}

To highlight parallels between classic German Pietism and Pentecostalism is not to ignore important divergences between the movements. Pietists were definitively, though also uniquely, sacramental. In Pia Desideria, Spener took pains to affirm his Lutheran theology. He quoted Luther's Small Catechism to praise the effect and power of baptism and confirmed that we receive "a pledge of our salvation in, with, and under the bread and the wine." 51 At the same time, Spener detested the dangers of opus operatum within certain Lutheran circles. Baptism was covenantal and required remaining in faith and a good conscience throughout one's life. Holy Communion was for strengthening the spiritual life, for proclaiming "the Lord's death with their hearts, lips, and life." 52 The early Pietists were Lutheran in doctrine and sacramental practice, including infant baptism, but they unfailingly were disturbed by the unchristian behavior manifest in much of (orthodox) Lutheranism.

While Pentecostals certainly participated in communion-usually with grape juice like other movements born during the temperance movement-and encouraged believer's baptism, they did not generally emphasize the sacraments' role to the degree that Pietists did in the salvation of the believer. For most, communion and baptism were ordinances, not sacraments; they were important and ordained by Jesus, but were not salvific in any way. ${ }^{53}$ Rather, Pentecostals followed Zwingli's lead and declared communion to be a symbol of Christ's work and baptism to be an outward sign of the inward work of God. ${ }^{54}$ Pentecostals did place a high value on an ecstatic experience with the divine, which they referred to as baptism with the Holy Spirit. While not salvific, it was key in providing the believer with sanctification, power, and spiritual intimacy with God. "This baptism [with the Holy Spirit]," wrote Pentecostal tract author 
Hattie M. Barth, "means the complete filling and possessing of a cleansed temple by the Holy Ghost. It means the sweetest communion, abiding in the holy of holies. The Spirit possesses to impart His own love and life and power." This baptism usually was evidenced by speaking in tongues. "When the Holy Spirit has complete control," continued Barth, "we find Him using our tongues." 55

\section{Manifestational Gifts}

When it comes to outward, manifestational gifts, Pietists and Pentecostals have taken different paths. While Francke's far-ranging undertakings manifested the marvelous footsteps of divine providence to anyone with eyes to see, one finds little focus within Pietism on miraculous healing, speaking in tongues, and other more dramatic signs of the Spirit's working. ${ }^{56}$ Such an observation is not to deny the epistemological importance of experience within Pietism.

Pentecostals, on the other hand, saw practices like speaking in tongues, prayer for divine healing, and prophetic utterances as evidence of the Spirit's presence on the earth and in the spiritual life of the practitioner. Pentecostal pioneer Agnes Ozman recalled her first experience with the baptism of the Holy Spirit and its subsequent manifestational gifts: "We were urged to seek for and to receive the promised baptism in the Holy Spirit. ... I spoke three words in another tongue. While I did not understand this manifestation then as I do now, it was a very precious and sacred experience." ${ }^{57}$ This emphasis on manifestations of the Spirit was so pronounced that Pentecostal sermons and literature suggested that any movement, meeting, or even individual prayer time that did not include some supernatural experience was lacking the presence of the Holy Spirit.

\section{Eschatology}

One final distinction between Pietism and Pentecostalism is eschatology. One of the ways in which Spener broke with the prevailing orthodoxy of his day was his optimistic (postmillennial) eschatology, his hope for better times. ${ }^{58}$ A part of what motivated the missional activism of Pietism was its conviction that it could contribute eschatologically to the betterment of the world and the inbreaking of God's reign.

Although the first generations of the Pentecostal movement had diverse ideas about the end of time or the world, they quickly concluded that the manifestations they experienced were signs of the imminent return of Christ and typically have embraced a premillennial eschatology. ${ }^{59}$ As early as 1908, Pentecostals were claiming the premillennial Second Coming of Christ as a central tenet of the movement. ${ }^{60}$ "The premillennial coming of our Lord Jesus has always been the hope of the true church," wrote Elizabeth A. Sexton. "It is only when the early church lost the fervency of her first love, that she departed from this hope." ${ }^{11}$

\section{Pietism as Translator and Channel}

Pietism and Pentecostalism share a number of parallels or commonalities: they are comfortable with the language of conversion, something they share (fascinatingly) with liberation theology; ${ }^{62}$ the authority of the Bible is grounded in experience; both sound clarion calls to personal holiness and praxis; in their own ways, each pursues missional activism; and they are united in opposing the dryness and conventionalism of the religious status quo. At the same time, the two movements have undeniable theological, ecclesiological, and functional differences.

Our modest hope is that those who are interested in Lutheran-Pentecostal dialogue might come to see German Lutheran Pietism as a useful translator and channel for conversation. On the one hand, Pentecostals often do not realize that continental Pietism was as influential as it was on the roots of Wesleyan-Holiness Pentecostalism - to say nothing of its influence on American Lutheranism in general. On the other hand, many present-day Lutherans have a deep-seated (and often irrational) 
wariness surrounding Pietism, and thereby overlook a portion of their own tradition that could assist them in ecumenical listening and understanding.

To play an intermediary role between denominations or movements is not new for Pietism. As the story of ecumenism's history is told and documented, Pietism holds a unique place. Martin Schmidt states that German Pietism "introduced a new epoch in the history of the ecumenical movement." 63 Pietism's ecumenicity, however, was not rooted in theological agreement or efforts at ecclesiological unity; rather, it arose out of praxis, mission, and spirituality. A similar focus might serve as a constructive starting point for current Lutheran-Pentecostal interactions.

As authors, our dialogue sprung from a sense of collegiality, which pressed us to presume the best in each other, to seek out commonalities and parallels, and to treat our honest differences with graciousness and respect. We make no claim that our observations and preferences represent any kind of systematic thoroughness; they surfaced out of relationship and forthright conversation. We are grateful for the opportunity to share publicly some of our reflections.

\section{Endnotes}

1. See World Council of Churches, "Documents related to the WCC programme "Ecumenical movement in the $21^{\text {st }}$ century," online at https://www.oikoumene.org/en/resources/documents/wcc-programmes/ ecumenical-movement-in-the-21st-century (accessed June 17, 2016).

2. This past September, Lutherans and Pentecostals met for the first time in an official international dialogue commission co-sponsored by the Lutheran World Federation. This dialogue was preceded by an important six-year consultation between a group of Lutheran and Pentecostal theologians at the Ecumenical Institute in Strasbourg, France, which produced the document, "Lutherans and Pentecostals in Dialogue," online at http://strasbourginstitute.org/wp-content/uploads/2012/08/Lutherans-andPentecostals-in-Dialogue-Text-FINAL.pdf (accessed September 2, 2016).

3. F. Ernest Stoeffler, The Rise of Evangelical Pietism (Leiden: E.J. Brill, 1965), 1.

4. On the lack of scholarly consensus around a common understanding of the nature and scope of Pietism, see Jonathan Strom, "Problems and Promises of Pietism Research," Church History 71 (2002): 547-549.

5. See Carter Lindberg, Introduction to The Pietist Theologians: An Introduction to Theology in the Seventeenth and Eighteenth Centuries, ed. Carter Lindberg (Oxford: Blackwell, 2005), 2-3; see also Strom, "Problems and Promises of Pietism Research," 537-541.
6. Johannes Wallmann, Der Pietismus (Göttingen: Vandenhoeck \& Ruprecht, 1990), 7; Philip Jacob Spener, Pia Desideria, trans. Theodore G. Tappert (Philadelphia: Fortress, 1964 [1675]).

7. Martin Brecht, Einleitung in Der Pietismus vom siebzehnten bis zum friihen achtzehnten Jahrhundert, ed. Martin Brecht (Göttingen: Vandenhoeck \& Ruprecht, 1993); W. R. Ward, The Protestant Evangelical Awakening (Cambridge: Cambridge University Press, 1992), 57-63.

8. Daniel L. Brunner, Halle Pietists in England (Göttingen: Vandenhoeck \& Ruprecht, 1993), 34.

9. Stoeffler, The Rise of Evangelical Pietism, 23.

10. [Anthony W. Boehm], Preface to Pietas Hallensis, by August H. Francke, [trans. A.W. Boehm] (London, 1705), xxxv; cf. Brunner, Halle Pietists in England, 34-35.

11. Stoeffler, Rise of Evangelical Pietism, 13-23; cf. Stoeffler, "Pietism: Its Message, Early Manifestation, and Significance," The Covenant Quarterly 34 (1976): 10-14.

12. D. W. Bebbington, Evangelicalism in Modern Britain: A History from the 1730s to the 1980s (London: Unwin Hyman, 1989), 1-17. For colloquia on Bebbington's definition, see Charlie Phillips, ed., "Roundtable: Re-Examining David Bebbington's 'Quadrilateral Thesis," Fides et Historia 47 (2015): 44-96; David Bebbington and David Ceri Jones, eds., Evangelicalism and Fundamentalism in the United Kingdom during the Twentieth Century (Oxford: Oxford University Press, 2013); Michael A. G. Haykin and Kenneth Stewart, eds., The Emergence of Evangelicalism: Exploring Historical Continuities (Nottingham: Apollos, 2008).

13. Mark A. Noll, The Rise of Evangelicalism: The Age of Edwards, Whitefield and the Wesleys (Nottingham: Inter-Varsity, 2004), 15.

14. See Daniel L. Brunner, "The 'Evangelical' Heart of Pietist Anthony William Boehm," in Heart Religion: Evangelical Piety in England and Ireland, 1690-1850, ed. John Coffey (Oxford: Oxford University Press, 2016), 72-92.

15. Kenneth J. Collins, The Theology of John Wesley: Holy Love and the Shape of Grace (Nashville: Abingdon Press, 2007), 208-211.

16. Leah Payne, "New Voices': Pentecostal Preachers in North America, 1890-1930," in Scripting Pentecost: A Study of Pentecostals, Worship, and Liturgy, ed. Mark J. Cartledge and A. J. Swoboda (New York: Routledge, 2016), 15-31.

17. Many revivalist scholars trace the practice to the eighteenth century during what usually is called the "Great Awakening." See, for example, Michael James McClymond, Embodying the Spirit: New Perspectives on North American Revivalism (Baltimore: Johns Hopkins University Press, 2004), 2; William Gerald McLoughlin, Revivals, Awakenings, and Reform: An Essay on Religion and Social Change in America, 1607-1977 (Chicago: University of Chicago Press, 1978), 1. Leigh Eric Schmidt, Holy Fairs: Scotland and the Making of American Revivalism, $2^{\text {nd }}$ ed. (Grand Rapids, Mich.: W.B. Eerdmans Publishing Company, 2001), traces the roots of this style of worship to post-Reformation Scotland.

18. McClymond, Embodying the Spirit, 6.

19. William H. Cooper, The Great Revivalists in American Religion, 1740-1944: The Careers and Theology of Jonathan Edwards, Charles Finney Dwight Moody, Billy Sunday and Aimee Semple Mcpherson (Jefferson, N.C.: McFarland \& Company, 2010), 32; Mark A. Noll, America's God: From Jonathan Edwards to Abraham Lincoln (New York: Oxford University Press, 2002), 295; George M. Marsden, Fundamentalism and American Culture, $2^{\text {nd }}$ ed. (New York: Oxford University Press, 2006), 11; Edith Waldvogel Blumhofer and Randall Herbert Balmer, Modern Christian Revivals (Urbana, Ill.: University of Illinois Press, 1993), xi.

20. See Brunner, Halle Pietists in England, 35-37.

21. Carter Lindberg, The Third Reformation? Charismatic Movements and the Lutheran Tradition (Macon, Ga.: Mercer University Press, 1983). 
22. Martin Luther, "Preface to the Letter of St. Paul to the Romans," trans. Andrew Thornton, OSB, online at http://www.ccel.org///luther/romans/pref_romans.html (accessed June 17, 2016). On the importance to Pietism of Luther's Preface to Romans, see Martin Schmidt, "Luthers Vorrede zum Römerbrief im Pietismus," in Wiedergeburt und neuer Mensch: Gesammelte Studien zur Geschichte des Pietismus (Witten-Ruhr: Luther-Verlag, 1969), 299-330.

23. See Erhard Peschke, "Speners Wiedergeburtslehre und ihr Verhältnis zu Franckes Lehre von der Bekehrung," in Traditio-KrisisRenovatio aus theologischer Sicht, ed. Bernd Jaspert and Rudolf Mohr (Marburg: N.G. Elwert, 1976), 206-224.

24. William Seymour, "Two Works of Grace and the Gift of the Holy Ghost," The Apostolic Faith 1, no. 1 (1906): 3.

25. Joseph Robbins, "A Helpful Life Story," in The Latter Rain Evangel 1 , no. 11 (1909): 8-9.

26. Ibid.

27. We follow Bebbington, Evangelicalism in Modern Britain, 12-14, in using the term biblicism; it refers not to biblical literalism but to devotion to the Bible and its divine inspiration.

28. [Anthony W. Boehm], Plain Directions for Reading the Holy Scripture, $2^{\text {nd }}$ ed. (London, 1721 [1708]), 20-21.

29. Stoeffler, Rise of Evangelical Pietism, 20-22.

30. John Walsh, "Methodism' and the Origins of English-Speaking Evangelicalism," in Evangelicalism: Comparative Studies of Popular Protestantism in North America, the British Isles, and Beyond, 1700 -1990, ed. Mark A. Noll, David W. Bebbington, and George A. Rawlyk (Oxford: Oxford University Press, 1994), 26; Ted A. Campbell, The Religion of the Heart: A Study of European Religious Life in the Seventeenth and Eighteenth Centuries (Columbia, S.C.: University of South Carolina Press, 1991), 17.

31. August Hermann Francke, An Abstratt of the Marvellous Footsteps of Divine Providence, [ed. and trans. A.W. Boehm] (London, 1706); cf. Brunner, Halle Pietists in England, 82-87.

32. "Report from Birmingham," The Bridegroom's Messenger 1, no. 5 (1908): 1 .

33. Grant Wacker, Heaven Below: Early Pentecostals and American Culture (Cambridge, Mass.: Harvard University Press, 2001), 70-86.

34. "Notes," The Latter Rain Evangel 1, no. 1 (1908): 14

35. "Report from Birmingham," 1.

36. Johannes Wallmann, Philipp Jakob Spener und the Anfänge des Pietismus (Tübingen: J.C.B. Mohr, 1970), 253-282.

37. Spener, Pia Desideria, 104.

38. Stoeffler, Rise of Evangelical Pietism, 16-20.

39. Susie Cunningham Stanley, Holy Boldness: Women Preachers'Autobiographies and the Sanctified Self (Knoxville, Tenn.: University of Tennessee Press, 2002), 82-85.

40. Anthea D. Butler, Women in the Church of God in Christ: Making a Sanctified World (Chapel Hill, N.C.: The University of North Carolina Press, 2007), 69-71; cf. Percy Given, "Deets Pacific Bible College," Nazarene Messenger 12, no. 1 (1907).

41. Charles Brougher Jernigan, Pioneer Days of the Holiness Movement in the Southwest (Kansas City, Mo.: Pentecostal Nazarene Publishing House, 1919), 7-8.

42. Butler, Women in the Church of God in Christ, 80-81; Vinson Synan, The Holiness-Pentecostal Tradition: Charismatic Movements in the Twentieth Century, $2^{\text {nd }}$ ed. (Grand Rapids, Mich.: W.B. Eerdmans Publishing Company, 1997), 34-35.

43. Martin E. Marty, in A Short History of Christianity, $2^{\text {nd }}$ ed. (Philadelphia: Fortress, 1987 [1959]), 225, wrote: "For all its glories,
Pietism was one of the major strides of Christian retreat from responsibility as it had been viewed in the past."

44. Brunner, Halle Pietists in England, 71-153.

45. Butler, Women in the Church of God in Christ, 3.

46. Annie Murray, "God is Working in Bombay, India," The Bridegroom's Messenger 4, no. 87 (1911): 1.

47. Stoeffler, Rise of Evangelical Pietism, 22.

48. [Boehm], Preface to Pietas Hallensis, xl.

49. F. L. Juillrat, "South Florida Pentecostal School," The Bridegroom's Messenger 1, no. 2 (1907): 3.

50. Samuel J. Mead, "On the Way to Africa," The Apostolic Faith 1, no. 6 (1907): 5.

51. Spener, Pia Desideria, 63.

52. Ibid., 65-67.

53. For example, see the Assemblies of God position paper on Baptism and Communion, in Earl Creps, "Water Baptism and Communion: Two ordinances, three tenses," in The Pentecostal Evangel, online at http://www.ag.org/pentecostal-evangel/Articles2002/ foundational_five.cfm\#autyhor (accessed June 29, 2016). See also the Church of God in Christ's discussion of the ordinances of communion, baptism, and foot washing, in "The Ordinances of the Church," in "What We Believe," online at http://www.cogic.org/about-company/whatwe-believe/ (accessed June 29, 2016).

54. See Roger E. Olson, The Story of Christian Theology (Downers Grove, Ill.: InterVarsity Press, 1999), 404-408.

55. Hattie M. Barth, "Justification, Sanctification, and the Baptism of the Holy Ghost," The Bridegroom's Messenger 2, no. 6 (1908): 2.

56. One exception is the report of revival among the children of Silesia in the early eighteenth century. See Praise Out of the Mouth of Babes, [trans. and ed., Anthony W. Boehm] (London, 1708); Ward, The Protestant Evangelical Awakening, 71-73.

57. Agnes Ozman, "The First One to Speak in Tongues," Latter Rain Evangel 1 (January 1909): 2.

58. Erich Beyreuther, "Evangelische Missionstheologie im 16. und 17. Jahrhundert," Evangelische Missionszeitschrift 18 (1961): 38-39. Johannes Wallmann, "Die Anfänge des Pietismus," Pietismus und Neuzeit 4 (1977/78): 49-53, states that Spener differed from orthodoxy only through his hopeful eschatology and his support of ecclesiolae in ecclesia.

59. The Augsburg Confession (1530) condemned the notion of an "earthly golden age." See Crawford Gribben, Evangelical Millennialism in the Trans-Atlantic World, 1500-2000 (New York: Palgrave Macmillan, 2011), 16.

60. See, for example, D. H. Hood, "Falcon Camp Meeting," The Bridegroom's Messenger 1, no. 17 (1908): 1; Elizabeth A. Sexton, "Editorials," The Bridegroom's Messenger 3, no. 58 (1910): 1; "A Statement of Fundamental Truths Approved by the General Council of the Assemblies of God, October 2-7, 1916," The Weekly Evangel no. 172 (1917): 8.

61. Sexton, "Editorials": 1.

62. For example, Gustavo Gutiérrez, We Drink from Our Own Wells, trans. Matthew J. O'Connell (Maryknoll, N.Y: Orbis, 2003 [1983]), 95, states that conversion is a requirement for solidarity with the poor: "A conversion is the starting point of every spiritual journey. It involves a break with the life lived up to that point. ... It presupposes also, and above all, that one decides to set out on a new path."

63. Martin Schmidt, "Ecumenical Activity on the Continent of Europe in the Seventeenth and Eighteenth Centuries," in A History of the Ecumenical Movement, 1517-1948, ed. Ruth Rouse and Stephen C. Neill, $2^{\text {nd }}$ ed. (London: SPCK, 1967 [1954]), 99. 